\title{
Effect of Soilless Growing Media on Yield and Quality of Tomato (Solanum lycopersicum L.) under Tropical Island Condition
}

\author{
T. Subramani*, B. Gangaiah, V. Baskaran and S. Swain \\ ICAR-Central Island Agricultural Research Institute, Port Blair, \\ Andaman and Nicobar Islands, India \\ *Corresponding author
}

\begin{abstract}
A B S T R A C T
The experiments with eight growing media as treatments were conducted in CRD with three replications at Garacharm Research Farm, ICAR-Central Island Agricultural Research Institute, Port Blair during 2017-19 in a naturally ventilated polyhouse from November to March with tomato hybrid 'Arka Rakshak' in grow bag (12 L). Eight treatments include cocopeat + vermiculite $(1: 1)$, cocopeat + perlite $(1: 1)$, cocopeat + sand (1:1), cocopeat + saw dust (1:1), cocopeat + vermiculite + saw dust $(1: 1: 2)$, cocopeat + perlite +saw dust (1:1:2), cocopeat + sand +saw dust $(1: 1: 2)$ and soil + farmyard manure (FYM) (3:1). Results showed that among different growing media, cocopeat + saw dust $(1: 1 \mathrm{v} / \mathrm{v})$ recorded maximum number of fruits/plant (12.33), fruit weight $(51.2 \mathrm{~g} / \mathrm{fruit})$, and finally fruit yield $(631 \mathrm{~g} /$ plant)and was at par with cocopeat + vermiculite + saw dust $(1: 1: 2)$. However, cocopeat + saw dust $(1: 1 \mathrm{v} / \mathrm{v})$ combination was cheaper than cocopeat + vermiculite + saw dust (1:1:2). Maximum Total soluble solids (TSS) of $6.75^{\circ} \mathrm{Brix}$ was recorded by cocopeat + saw dust $(1: 1 \mathrm{v} / \mathrm{v})$, whereas higher ascorbic acid $(16.46 \mathrm{mg} / 100 \mathrm{~g})$ and lycopene $(6.8 \mathrm{mg} / 100 \mathrm{~g})$ contents were recorded by cocopeat + vermiculite (1:1). Growth, yield and quality parameters recorded in the control i.e., soil + FYM were least. Hence, it can be concluded that cocopeat + saw dust $(1: 1 \mathrm{v} / \mathrm{v})$ as economically and environmentally sustainable media for soilless cultivation of tomato under island condition.
\end{abstract}

\section{Introduction}

Vegetable production in Andaman and Nicobar Islands is low due to open field cultivation that was confronted with plethora of problems like heavy and continuous rain, water logging, pest and diseases. The demand of vegetables far exceeds their production in the islands, necessitating their transport from mainland that results in not only high cost of vegetables in the markets but also their impaired quality by the time they reach consumer. Among the vegetables, tomato being the most widely used nutritive vegetable and thus has high demand in the islands throughout the year.Tomato being a warm season crop requires a relatively long growing season and moderately high temperature. With the availability of high value agriculture scheme, many farmers are 
resorting to vegetable cultivation in polyhouses. However, the productivity is not encouraging due to incidence of soil related pest and diseases. The problems with production factors such as soil salinity, lack of arable soil, water have led to the development of substrates for soilless cultivation (Olympios, 1999). Soilless culture is a technique where crops are cultivated in a soil less growth media by supplying nutrients in solution. Here the chances of pests, diseases and weeds are eliminated. The changing health concern of people also demands high quality food. But in Andaman and Nicobar Islands, where there are hostile weather conditions and degraded soils, the production of fresh vegetables is a great challenge. The soilless cultivation is therefore, a possible alternative which reduces the soil related problems experienced in the conventional crop cultivation. Soilless culture is adopted as a means of replacing the natural soil system with either an aerated solution or an artificial soil composed of chemically inert aggregates moistened with nutrient solutions. The common types of media used in soilless culture are perlite, spagnum moss, gravel, rock wool, saw dust, vermiculite, cocopeat and peat moss. Plants grown in soil less culture has consistently superior quality, high yield, rapid harvest, and high nutrient content (Hussain et al., 2014). Moreover, soilless growing media are easier to handle and may provide a better growing environment compared to soil (Mastouri et al., 2005). Among several growing media, coco-peat is considered as a wonderful growing media with suitable $\mathrm{EC}, \mathrm{pH}$ and other chemical properties. Coco-peat has high water holding capacity and its high air filled porosity results in very high seed germination rate and produces more stronger and fibrous seedlings (Fornes et al., 2003). The major constraints in the islands are limited availability of productive lands, fertilizers and irrigation water. Huge quantity of cocopeat and saw dust, the by-products of coconut industry and saw mill available in the islands can be used as a media for soilless cultivation. Hence, soilless cultivation under protected structures will be the alternate techniques for tomato cultivation in the islands which don't require soil and saves fertilizers and water. Under this context, the experiments were conducted to study the effect of soilless growing media on yield and quality of tomato under tropical island ecosystem.

\section{Materials and Methods}

\section{Location and climate}

The experiments were conducted at Garacharma Research Farm, ICAR-Central Island Agricultural Research Institute, Port Blair during 2017-19 in a naturally ventilated polyhouse from November to March. The naturally ventilated polyhouse was made of 200 micron UV stabilized LDPE Sheet. The length, width and height of polyhouse were $25 \times 10 \times 4 \mathrm{~m}$. The area is located at $11^{\circ}$ 36'44.16" N Latitude and $92^{\circ} 42^{\prime} 51.04$ ' E Longitude. The mean minimum and maximum temperature ranged between 26 to $35^{\circ} \mathrm{C}$. The relative humidity ranged between 71 and 75 .

\section{Crop and variety}

As tomato was the first crop produced by hydroponics and has high market demand in the islands, the tomato $F_{1}$ hybrid 'Arka Rakshak' developed by IIHR, Bangalore was chosen for the study. The duration of crop was140 days and the fruit size is medium to large.

\section{Experimental design}

The seedlings of tomato were raised in portrays and transplanted after 25 days in grow bag ( $24 \times 24 \times 40 \mathrm{~cm}$ size) consisting of growing media (substrate volume: $12 \mathrm{~L}$ ) as 
per the treatment schedule. The experiment was conducted with eight treatments i.e. cocopeat + vermiculite $(1: 1)$, cocopeat + perlite $(1: 1)$, cocopeat + sand $(1: 1)$, cocopeat + saw dust (1:1), cocopeat + vermiculite +saw dust (1:1: 2), cocopeat + perlite +saw dust (1:1: 2$)$, cocopeat + sand +saw dust $(1: 1: 2)$ and soil + farmyard manure (FYM) (3:1). The experiment was laid out in completely randomized block design with 6 replications. Recommended package of practices and need based plant protection measures were adopted.

\section{Nutrient solution}

Coeper (1988) nutrient solution comprising of (mg/ L) N 236, P 60.0, K 300, Ca 85, Mg 50, S 68, Fe (EDTA) 12, Mn 2.0, Zn 0.1, Cu 0.1 , B 0.3, Mo 0.2 was used for the study. The quantity and concentration of nutrient solution applied was equal for all the treatments. The irrigation volume was gradually increased as plants grow and to ensure complete wetting of growing media in the bag. The total quantity of nutrient solution used for entire growth period was $95 \mathrm{~L} /$ plant.

\section{Data collection and analysis}

Growth, yield parameters and yield of tomato were recorded. The quality parameters viz., total soluble solids ( ${ }^{\circ}$ Brix), titrable acidity (\%), ascorbic acid content $(\mathrm{mg} / 100 \mathrm{~g})$ and lycopene content $(\mathrm{mg} / 100 \mathrm{~g})$ were determined. The data was subjected to statistical analysis as per the methods out lined by Panse and Sukhatme (1985). The data pertaining to growth, yield parameters, yield and quality parameters along with their statistical interpretations are presented and discussed.

\section{Results and Discussion}

During the course of experiment, plant growth, yield and quality of the produce under different treatments were critically observed and discussed.

\section{Growth attributes}

The data on growth attributes were presented in table 1. The growing media combinations have significantly influenced the plant height of tomato. In general, the plant height ranged between 106 and $136 \mathrm{~cm}$. Among the growing media combinations, cocopeat + sawdust (1:1) recorded higher plant height $(136 \mathrm{~cm})$ and at par with cocopeat + vermiculite + sawdust (1:1:2). The plant height was the lower $(106 \mathrm{~cm})$ in soil + FYM (3:1). However, cocopeat + vermiculite + sawdust $(1: 1: 2)$ recorded maximum number of branches (7.8) and dry matter production (116 $\mathrm{g} /$ plant) which is on par with cocopeat + sawdust (1:1) and cocopeat + vermiculite $(1: 1)$. The crop that flowers or fruits earlier is known to add additional income to the farmers by exploiting the market demand in the early days of the season. The days to 50 per cent flowering and first harvest of tomato were ranged between 28 to 33 days after transplanting (DAT) and 58 to 63 DAT, respectively. Among the treatments, cocopeat + vermiculite (1:1) was found to be earliest to 50 per cent flowering (28 DAT) and first harvest ( 58 DAT) and at par with cocopeat +saw dust (1:1) and cocopeat + vermiculite + sawdust (1:1:2) as compared to other growing media combinations.

The better growth performance of tomato plants in cocopeat+ saw dust may be due to the high water holding capacity, aeration, reduced bulk density and slightly high potassium content in the medium. The studies conducted by various researchers also reported that cocopeat and saw dust had significant effect on the plant growth (Yau and Murphy, 2000, Muro et al., 2005, Peyvast et al., 2010, Arias et al., 2014 and Reshma and Sarath, 2017). 


\section{Yield attributes}

The data on yield attributes are presented in table 2. Growing media have significantly influenced the number maximum number of fruits/plant (12.33) and at par with cocopeat + vermiculite + saw dust (1:1:2) as compared to other soilless growing media combinations. The fruits per plant were minimum in control i.e. Soil + FYM. Similarly, cocopeat + saw dust (1:1) media recorded higher fruit length $(5.3 \mathrm{~cm})$ and fruit girth $(5.0 \mathrm{~cm})$ of tomato. It was at par with cocopeat + vermiculite $(1: 1)$, cocopeat + vermiculite + saw dust $(1: 1: 2)$ and cocopeat + perlite + saw dust $(1: 1: 2)$ for fruit length and cocopeat + vermiculite $(1: 1)$ and cocopeat + vermiculite + saw dust $(1: 1: 2)$ for fruit girth. The nature of growing media significantly increased the fruit weight of tomato. The cocopeat + saw dust (1:1) media recorded higher fruit weight $(51.2 \mathrm{~g} /$ fruit $)$ and at par with cocopeat + vermiculite + saw dust (1:1:2) as compared to other growing media combinations. The minimum fruit weight of $40 \mathrm{~g} /$ plant was recorded by soil + FYM. The better yield attributes recorded in cocopeat + sawdust media may be due to good anchorage and supply of water and nutrients in this medium. Yau and Murphy (2000) reported that composted cocopeat recorded higher fruit number and fruit weight of tomato. Similar findings were also reported by Reshma and Sarath (2017) who recorded higher yield attributes of tomato under cocopeat medium. Ranjit Singh Spehia (2019) also reported that soilless culture with cocopeat + vermicompost (70:30, w/w) irrigating at $50 \%$ ETc on daily basis recorded higher yield attributes and yield of tomato.

\section{Yield}

The results revealed that among different growing media, cocopeat + saw dust $(1: 1 \mathrm{v} / \mathrm{v})$ recorded maximum number of fruits/plant and fruit weight that resulted in higher fruit yield
(631 g/plant) and at par with cocopeat + vermiculite + saw dust $(1: 1: 2)$. It was followed by cocopeat + vermiculite and cocopeat + perlite + saw dust $(1: 1: 2)$. The lowest yield (341 g/plant) was recorded in control i.e. soil + FYM (3:1). Among the growing media combinations, cocopeat + saw dust $(1: 1 \mathrm{v} / \mathrm{v})$ and cocopeat + vermiculite + saw dust $(1: 1: 2 \mathrm{v} / \mathrm{v})$ proved the best. The findings established the beneficial effects of cocopeat and saw dust on the yield and its associated attributes in tomato. Asha Joseph and Muthuchamy (2014) have reported that the maximum yield of tomato was recorded for the treatment trough with cocopeat+gravel+silex stone. Natarajan and Kathandaraman (2018) also recorded higher yield of tomato under cococpeat + vemicompost+ vermiculite (1:1:1) medium. The results are in agreement with Jackson and Wright (2009), who recommended saw dust to be used as a substrate in the greenhouse, due to its low cost and easy availability.

\section{Quality parameters}

Quality characters are very important in vegetables like tomato because they impart nutritional and processing quality of the produce. High total soluble solids (TSS) and low acidity are the preferred qualities for manufacture of various processed products. In general soilless culture reported to increase the tomato fruits quality greatly around the world.In the present study, different growing media combinations showed variation for quality characters like TSS and ascorbic acid. Tomato grown in cocopeat + saw dust recorded maximum TSS of $6.75^{\circ}$ Brix which was at par with cocopeat + vermiculite $(1: 1)$ and cocopeat + vermiculite + saw dust (1:1:2) whereas, minimum TSS $\left(4.95^{\circ}\right.$ Brix $)$ was recorded in soil +FYM. However, higher ascorbic acid content $(16.46 \mathrm{mg} / 100 \mathrm{~g})$ and lycopene content $(6.8 \mathrm{mg} / 100 \mathrm{~g})$ were recorded by cocopeat + vermiculite $(1: 1)$ 
which is at par with cocopeat + saw dust (1:1)and cocopeat + vermiculite + saw dust $(1: 1: 2)$ as compared to soil + FYM (3:1). The finding established the inverse relationship between the yield and quality attributes of tomato. Very good variation among growing media for quality characters was also observed by Maboko and Plooy (2009).However, there was no significant difference among different media and soil for titrable acidity of tomato fruit (Table 3).

Table.1 Growth attributes of tomato as influenced by different growing media (pooled analysis of two seasons)

\begin{tabular}{|l|c|c|c|c|c|}
\hline \multicolumn{1}{|c|}{ Treatment } & $\begin{array}{c}\text { Plant } \\
\text { Height } \\
\text { (cm) }\end{array}$ & $\begin{array}{c}\text { Number } \\
\text { of } \\
\text { branches/ } \\
\text { plant }\end{array}$ & $\begin{array}{c}\text { Plant dry } \\
\text { weight } \\
\text { (g/plant) }\end{array}$ & $\begin{array}{c}\text { Days to } \\
\mathbf{5 0} \text { \% } \\
\text { floweri } \\
\text { ng }\end{array}$ & $\begin{array}{c}\text { Days to } \\
\text { first } \\
\text { harvest }\end{array}$ \\
\hline Cocopeat + Vermiculite (1:1 v/v) & 119 & 7.0 & 110 & 28 & 58 \\
\hline Cocopeat + Perlite (1:1) & 116 & 6.0 & 98 & 30 & 61 \\
\hline Cocopeat + Sand (1:1) & 115 & 5.5 & 97 & 31 & 63 \\
\hline Cocopeat + Sawdust (1:1) & 136 & 7.3 & 113 & 29 & 59 \\
\hline $\begin{array}{l}\text { Cocopeat + Vermiculite +Sawdust } \\
\text { (1:1: 2) }\end{array}$ & 129 & 7.8 & 116 & 29 & 58 \\
\hline Cocopeat + Perlite +Sawdust (1:1: 2) & 122 & 6.2 & 101 & 31 & 59 \\
\hline Cocopeat + Sand +Sawdust (1:1: 2) & 120 & 5.3 & 97 & 32 & 62 \\
\hline Soil + Farmyard manure (FYM) (3:1) & 106 & 5.5 & 92 & 33 & 63 \\
\hline SEm \pm & 3.8 & 0.3 & 4.2 & 0.5 & 0.5 \\
\hline CD (p=0.05) & 10.9 & 0.9 & 11.9 & 1.4 & 1.5 \\
\hline
\end{tabular}

Table.2 Yield attributes and yield of tomato as influenced by different growing media (pooled analysis of two seasons)

\begin{tabular}{|l|l|l|l|l|l|}
\hline Treatment & $\begin{array}{l}\text { No of } \\
\text { fruits } \\
\text { /plant } \\
\text { (Nos) }\end{array}$ & $\begin{array}{l}\text { Fruit } \\
\text { lengt } \\
\text { h } \\
\text { (cm) }\end{array}$ & $\begin{array}{l}\text { Fruit } \\
\text { girth } \\
\text { (cm) }\end{array}$ & $\begin{array}{l}\text { Single } \\
\text { fruit } \\
\text { weight } \\
\text { (g) }\end{array}$ & $\begin{array}{l}\text { Fruit } \\
\text { yield } \\
\text { (g/plan } \\
\text { t) }\end{array}$ \\
\hline Cocopeat + Vermiculite (1:1 v/v) & 11.00 & 5.1 & 4.9 & 45.8 & 507 \\
\hline Cocopeat + Perlite (1:1) & 10.17 & 4.9 & 4.7 & 44.4 & 452 \\
\hline Cocopeat + Sand (1:1) & 10.00 & 4.7 & 4.5 & 43.9 & 440 \\
\hline Cocopeat + Sawdust (1:1) & 12.33 & 5.3 & 5.0 & 51.2 & 631 \\
\hline Cocopeat + Vermiculite +Sawdust (1:1: 2) & 12.00 & 5.1 & 4.8 & 49.8 & 598 \\
\hline Cocopeat + Perlite +Sawdust (1:1: 2) & 10.67 & 5.0 & 4.7 & 45.2 & 483 \\
\hline Cocopeat + Sand +Sawdust (1:1: 2) & 10.25 & 4.8 & 4.5 & 44.0 & 450 \\
\hline Soil + Farmyard manure (FYM) (3:1) & 8.50 & 4.7 & 4.5 & 40.0 & 341 \\
\hline SEm \pm & 0.37 & 0.12 & 0.09 & 0.8 & 19.9 \\
\hline CD (p=0.05) & 1.05 & 0.35 & 0.24 & 2.8 & 56.8 \\
\hline
\end{tabular}


Table.3 Influence of different soilless growing media on quality of tomato (pooled analysis of two seasons)

\begin{tabular}{|l|c|c|c|c|}
\hline Treatment & $\begin{array}{c}\text { TSS } \\
(\mathbf{0} \text { brix) }\end{array}$ & $\begin{array}{c}\text { Titrable } \\
\text { Acidity } \\
(\mathbf{\%})\end{array}$ & $\begin{array}{c}\text { Ascorbic } \\
\text { acid } \\
(\mathbf{m g} / \mathbf{1 0 0} \mathbf{g})\end{array}$ & $\begin{array}{c}\text { Lycopene } \\
(\mathbf{m g} / \mathbf{1 0 0} \mathbf{g})\end{array}$ \\
\hline Cocopeat + Vermiculite (1:1) & 6.45 & 0.31 & 16.46 & 6.8 \\
\hline Cocopeat + Perlite (1:1) & 5.55 & 0.29 & 15.01 & 6.3 \\
\hline Cocopeat + Sand (1:1) & 5.47 & 0.27 & 14.87 & 6.2 \\
\hline Cocopeat + Sawdust (1:1) & 6.75 & 0.30 & 15.73 & 6.5 \\
\hline Cocopeat + Vermiculite +Sawdust (1:1: 2) & 6.15 & 0.31 & 16.37 & 6.6 \\
\hline Cocopeat + Perlite +Sawdust (1:1: 2) & 5.30 & 0.28 & 14.48 & 6.2 \\
\hline Cocopeat + Sand +Sawdust (1:1: 2) & 5.28 & 0.27 & 14.96 & 6.1 \\
\hline Soil + Farmyard manure (FYM) (3:1) & 4.95 & 0.28 & 14.15 & 6.2 \\
\hline SEm \pm & 0.26 & 0.01 & 0.34 & 0.13 \\
\hline CD $(\mathbf{p = 0 . 0 5 )}$ & 0.72 & $\mathrm{NS}$ & 0.96 & 0.39 \\
\hline
\end{tabular}

From the two years study, it is concluded that cocopeat + saw dust $(1: 1 \mathrm{v} / \mathrm{v})$ and cocopeat + vermiculite + saw dust $(1: 1: 2)$ as the ideal medium from yield point of view. However, cost wise cocopeat + saw dust $(1: 1 \mathrm{v} / \mathrm{v})$ was cheaper to cocopeat + vermiculite + saw dust $(1: 1: 2)$. Further, cocopeat and saw dust are renewable, easily available and easier to dispose and thus are economically and environmentally sustainable media for soilless cultivation of tomato The findings from the study can be helpful to the growers involved in protected cultivation of tomato for utilizing locally available growing media, saving water and nutrients and maximizing production in the islands .

\section{References}

Arias, A.R. and Bustamante, W.O. 2014. Saw dust and coco coir as growing media for green house cherry tomato. Acta Hort. DOI:10.17660/ Acta Hortic. 2014.1037.140.

Cooper, A. 1988. "1. The system. 2. Operation of the system". In: The $A B C$ of NFT. Nutrient Film Technique, 3123, Grower Books (ed.), ISBN
0901361224, London, England.

Fornes, F., Belda, R. M., Abad, M., Noguera, P., Puchades, R., Maquieira, A. and Noguera, V. 2003. The microstructure of coconut coir dusts for use as alternatives to peat in soilless growth media. Australian Journal of Experimental Agriculture, 43: 11711179.

Hussain, A., Iqbal, K., Aziem, S., Mahato, P. and Negi, A. K. 2014. A review on the science of growing crop without soil (soilless culture) a novel alternative for growing crops. International Journal of Agriculture and Crop Sciences, 7: 833842.

Jackson, B.E. and Wright, R.D. 2009. Pine tree substrate an alternative and renewable substrate for horticultural crop production. Acta Hort. 819: 265 272.

Joseph, A. and Muthusamy I.2014. Productivity, quality and economics of tomato cultivation in aggregate hydroponics - A case study from Coimbatore region of Tamil Nadu. Indian J Sci Technol. 7 (8): 1078-1086.

Maboko, M. M. and Plooy, C. P. 
2009.Comparative performance of tomato cultivars in soilless Vs. insoil production system. ActaHortic. 843: 314-318.

Massa, D., Incrocci, L., Maggini, R., Carmassi, G., Campiotti, C. A. and Pardossi, A. 2010. Strategies to decrease water drainage and nitrate emission from soilless cultures of greenhouse tomato. Agricultural Water Management. 97: 971-980. doi: 10.1016/j.agwat.2010.01.029

Mastouri, F., Hassandokht, M.R. and Padasht Dehkaei, M.N. 2005. The effect of application of agricultural waste compost on growing media and greenhouse lettuce yield. ActaHort, 697:153-158.

Muro, J., Irigoyen, I., Samitier, P., Mazuela, P, Salas, M.C., Soler, J. AndUrrestarazu, M. 2005. Wood fibre as growing media in hydroponic crop. Acta Hort. 697: 179 - 185

Natarajan T. and Kothandaraman, A. 2018. Standardization of grow bag media with nutriseed pack fertilization for tomato crop under matric suction irrigation. Current Agriculture Research Journal 6 (3). doi:http://dx.doi.org/10.12944/carj. 6.3.25.
Olympios, C.M. 1999. Overview of soilless culture: advantages, constraints and perspectives for its use in Mediterranean countries. Cahier option Mediterranean's, 31: 307-324.

Panse, V.G. and Sukhatme, P.V.1985. Statistical methods for Agricultural workers. Indian Council of Agricultural Research. New Delhi. pp. 87-89.

Peyvast, G.H., Olfati, J.A., Kharazi, P.R. and Roudsari, O.N. 2010. Effect of substrate on greenhouse cucumber production in soilless culture. Acta Hort. 871: 429436.

Ranjit Singh Spehia. 2019. Standardization of soilless media and irrigation schedule for improving yield and quality of tomato in UV stabilized polybags under polyhouse. Ph.D Thesis. Lovely Professional University, Punjab, India. . $107 \mathrm{p}$.

Reshma, T. and Sarath, P.S. 2017. Standardization of growing media for the hydroponic cultivation of tomato. Int.J.Curr.Microbiol.App.Sci. 6(7): 626631.

Yau, P.Y. and Murphy, R.J. 2000. Biodegraded coco peat as a horticultural substrate. Acta Hort. 517: 275- 278.

\section{How to cite this article:}

Subramani, T., B. Gangaiah, V. Baskaran and Swain, S. 2020. Effect of Soilless Growing Media on Yield and Quality of Tomato (Solanum lycopersicum L.) under Tropical Island Condition. Int.J.Curr.Microbiol.App.Sci. 9(05): 2084-2090.

doi: https://doi.org/10.20546/ijcmas.2020.905.239 